\title{
Canada's Liberals promise money for science
}

Quebec. Canada's Liberal Party has promised to double the amount of money the country spends on research and development if it wins the federal election on 25 October. The party leader, Jean Chrétien, says that a Liberal government would invest an additional C $\$ 1$ billion in R\&D over the next four years.

The Liberal party, which is challenging the ruling Conservatives, claims that the country's principal failure in dealing with research and innovation lies in its inability "to gather, finance, administer, diffuse and market technology".

As a result, it promises to establish a "technology network" linking universities, industry associations and both federal and provincial governments, in order to make scientific and technical information more readily available to industry.

But it also says that its pledge to double R\&D spending will depend on the country "demonstrating its ability to absorb and manage such an increase".

The promised increase in the research budget forms part of a package of promises totalling an estimated C\$5.35 billion over four years. The extra costs would be offset by cutting $C \$ 7.1$ billion from existing public programmes.

A large part of the reduction would come from cancellation of the $C \$ 5.8$ billion, 13year programme to purchase military helicopters. The Prime Minister, Mrs Kim Campbell, when she was defence minister, described the programme as untouchable. But once an election was under way she agreed to reduce the number of helicopters

\section{Information superhighway takes off}

Washington. The Clinton administration has published a nine-point "agenda for action" designed to encourage the construction of a national information infrastructure which, it hopes, will provide a high-speed telecommunications link to every home and office in the United States.

Vice President Al Gore said last week that the federal government would act as a "catalyst" for the infrastructure, which will be built by the private sector. "No one should have any doubt how important this is to this administration", said Gore.

The agenda published by the White House promises to ensure that the so-called information superhighway is available to all "at affordable prices", that the intellectual property rights of its users and service suppliers will be safeguarded and that the superhighway is compatible with international networks.

Commerce secretary Ron Brown says that his department has already discussed the laws needed to establish the network with 300 interested parties, one hundred of which were involved in drafting the 24-page agenda. The document promises to formalize consultation by setting up a 25 -member advisory council.

Brown has invited nominations for the council, to be announced by December. Its make-up has not yet been settled. But universities and schools that want to use the network are likely to be represented. So, too, are industrial and commercial users, as well as the telecommunications and computer industries that will build it.

Legislation authorizing government agencies to provide several hundred million dollars of research and development funding for the proposed infrastructure is going well, and may even be passed next month.
The research and development law has already been passed in the House of Representatives, and an equivalent measure is being considered in the Senate as part of the larger National Competitiveness Act. Once the Senate act is passed, it will have to be reconciled with two corresponding Acts already passed by the House (see Nature $\mathbf{3 6 3}$, 104: 1993).

The parts of those laws dealing with the information infrastructure are broadly consistent with each other. They call for federal agencies such as the National Science Foundation and the National Institute of Standards and Technology to develop applications for the superhighway and to set up prototypes which will be transferred to the private sector as quickly as is practicable.

Colin Macilwain

\section{Centre will co-ordinate Arctic research}

Helsinki. In a move to coordinate the efforts of research organizations and initiatives studying environmental change in the Arctic, the International Arctic Science Committee has set up a Global Change Programme Office, based at the University of Lapland's Arctic Centre in Rovaniemi, Finland.

The office is headed by the director of the Arctic Centre, Manfred Lange. It will support and help to implement scientific projects concerning climatic changes and their effects on the Arctic region. According to Lange, one of its main functions will be to help to avoid overlap between the various programmes which address Arctic issues.

The creation of the new office is also intended to help focus on the pivotal role of the Arctic in climate change, covering both to 43 from 50 . Chrétien says he now wants to eliminate all of them.

The Liberal party's promise of support for science comes at a time when the ruling Conservatives have been severely criticized for their poor record in science funding. Perhaps the most serious blow to the Conservatives' credibility has been the resignation of Pierre Perron as president of the National Research Council (NRC) almost a year before his five-year term of office was due to end.

In a letter to the council's employees at the end of last month. Perron outlined the serious implications of deep budget cuts and what he described as the "anaemic support of R\&D" by the government. The latest cuts, announced at the end of July, will raise the potential annual shortfall to some 10-15 per cent of NRC's operating budget between 1995 and 2000, Perron said.

"If Canada is to catch up with the average of the G-7 countries, governments at all levels would have to more than double their investments in R\&D over the coming years, while industry would have to increase theirs by a factor of three to four", he wrote. "Some 15,000 to 20,000 new jobs in R\&D would have to be created every single year for almost a full decade."

Perron claimed that the government was overwhelmingly preoccupied with "the rate of growth and the national debt". As a result, the focus is on potential short-term savings, ignoring negative long-term impacts.

For this reason, NRC has decided to present a case for its next long-range plan (1995-2000) early in the fall, Perron said. It will seek a new funding base of some C\$260 million a year for its operating budget (an increase of C $\$ 10$ million), and additional one-time funding of C $\$ 112$ million for R\&D in key areas.

David Spurgeon the impact of change on the Arctic and the resulting feedback. "Given the fragile balances that sustain life in the Arctic and Antarctica, a rise in the temperature of 4 to 6 degrees over about a hundred years, as predicted by some computer models, might have devastating effects on polar ecosystems", says Lange.

The new office in Rovaniemi is intended as an information clearing house, linked to the multidisciplinary activities of the Arctic Centre. In addition to monitoring and advising on projects in the natural sciences, the office aims to bridge some of the gaps between these and Arctic research in social and economic fields, thus widening the scope of scientific enquiry to cover human influences on the natural environment.

Mark Waller 